\title{
Arthropods in Two Organic Agro-Ecosystems; Biodiversity, Distribution, and Weeds Impacts
}

\author{
Islam M. Zidan ${ }^{1}{ }^{\natural}$, Mourad F. Hassan², Gomaa M. Abou-Elella ${ }^{1}$, Elsayed M. K. El-Saeidy ${ }^{1}$ and Mohamed S. Nawar ${ }^{2}$ \\ 1 Pests and Plant Protection Department, Biological and Agricultural Research Division, National Research \\ Centre (NRC). El-Bohouth St., Dokki, P.O. 12622 Dokki, Giza, Egypt. \\ 2 Zoology and Agricultural Nematology Department, Faculty of Agriculture, Cairo University, Gamaa St., \\ 12613 Giza, Giza, Egypt. \\ ${ }^{\square}$ Corresponding: im.zidan@nrc.sci.eg, Orcid ID https://orcid.org/0000-0003-0186-7784
}

\begin{abstract}
Due to a lack of knowledge about arthropod biodiversity in Egyptian organic agro-ecosystems; the study aimed to introduce information on the diversity, richness, and distribution of insect and mite species in two organic agro-ecosystems, also, to investigate the impact of plantarthropod interactions. Samples collected from two organic farms, i) Shampoliah farm, Fayoum (GCS 29²1'07.4"N 3044'17.8"E), and ii) SEKEM farm, Sharkia (GCS 30²2'56.1"N 31'39'17.4"E). Results shown 39 species recorded in Shampoliah farm, and 35 species in SEKEM of mite, insect, medicinal, and weed species. When 14 species shared among two cites. Study has measured the H', D and 1/D indices within each location, and the similarity/dissimilarity between locations. The study hypothesized the possible plant-arthropod interactions that explain why diversity differs from an ecosystem to another; due to; plant size, plant morphological characters, soil fertilization, plant nutritional content, and the prey-predator interactions. The added hypothesis; is to show that the importance of natural habitat is supporting natural enemies and distribution of arthropods, which could vary dramatically with the type of pest species, IPM, and landscape type considered.
\end{abstract}

Keywords: mites; insects; trophic relation; plant-arthropod interactions;

SEKEM; fayoum

\section{Introduction}

In Africa, there are two million hectares of certified organic agricultural land area. According to the Research Institute of Organic Agriculture FiLB; the first three countries with the most organic land area are; Tunisia (286,623 hectares), Tanzania (278,467 hectares), and Ethiopia (221,189 hectares) (FiLB, 2021). While, Egypt is in the top ten (116,000 hectares), and the fourth of the countries with the highest organic share of total agricultural land in 2019. In Egypt, the official information about the actual organic agricultural size is very scarce. According to the FiLB and The International Federation of Organic Agriculture Movements (IFOAM) reports from 2016 to 2019; the distribution of total organic land area among Egypt's governorates, Behera Governorate is the largest area (29,972 hectares), and Fayoum Governorate is the second (27,218 hectares), both governorates representing more than half of Egypt's total organic area (54\%). While, Ismailia, New Valley, Beni Suif, Menia, Sharkia, and Sohag governorates are sharing about $15 \%$. Medicinal and ornamental plants were representing $26.5 \%$ of the cultivated organic products (28,066 hectares) (Siam and Abdelhakim, 2019).

The official Egyptian biodiversity website stated that there is more than 15,000 insect species and more than 1,500 arachnid species of mites, ticks, scorpions and spiders as terrestrial fauna, and more than 1,800 invertebrate species in aquatic fauna (Available at: https://www.egyptheritage.com/BiodiversitySite/Biodiversity/index.html). Nevertheless, some studies have revealed arthropod biodiversity in different Egyptian agro-ecosystems (AboShnaf et al., 2008; Sallam et al., 2010; Sawaby, et al., 2010; El-Sanady and Mohamed, 2013; 
Imam and Sawaby, 2013 a \& b; Zaki et al., 2015; Abd El-Karim, et al., 2016; Abo-Shnaf et al., 2016; Rizk, et al., 2017; Zaki and Aly, 2018; 2019; Zaki and Abo-Shnaf, 2018; El-Sheikh, et al., 2020; Zaki, 2021). Also, genera of phylum Nematoda, Meloidogyne Göldi, 1889 was the most dominant genus, and Xiphinema Cobb, 1913 was the rarest genus recorded in SEKEM (Adam et al., 2013). Few studies indicated the definite biodiversity indices to understand the actual arthropod community's structure.

Biological diversity measured in two ways; actual and perceived biodiversity (Magurran, 2013), and recently there is a conceptual hypothesis of different pathways linking biodiversity to human health (Marselle et al., 2021). In addition, the agro-ecosystem (economic crops) and the surrounding landscape (spontaneous plants) are relevant to biodiversity conservation. That, the presence of various weed species contributes to informal biodiversity, even, in urban greenspaces (Phillips and Lindquist, 2021).

Organic agriculture supports the conservation of biodiversity, when arthropod (insects and mites) species richness and abundance in organic agricultural eco-systems increased, as well as, the richness of species within trophic guilds (phytophagous, predators, pollinators, and parasitoids) (Underwood et al., 2011). Thus, both the faunal and/or floral biodiversity in an agroecosystem have significant impacts on biodiversity conservation, contributing to ecosystem functioning, the recycling of nutrients, integrated pest management applications, and increasing crop health and productivity (Bengtsson et al., 2005; Tropek et al., 2010; Simoni et al., 2013; Montañez and Amarillo-Suárez, 2014; Gardarin et al., 2018; Alistair et al., 2021).

It was a shred of evidence in soil biodiversity and distribution, when Oribatida, Astigmata, Prostigmata, and Mesostigmata have the largest differences among different aged Italian organic farms (Simoni et al., 2013). Arthropod community structure varied across flowering plant species; it has resulted that a single flower species attracted a different group of beneficial arthropods, similarly, a mixture of plant species could attract several arthropod taxa (Bennett and Gratton, 2013). Therefore, the study was aimed to introduce new information about insect and mite species diversity in the Egyptian organic agro-ecosystems and to hypothesized new understanding of the Arthropod-Plant interactions.

\section{Material and Methods}

\section{Locations}

Samples were collected from two certified organic farms on Egypt, i) SEKEM farm, Sharkia Governorate (GCS 30² $\left.56.1^{\prime \prime N} 31^{\circ} 39^{\prime} 17.4^{\prime \prime E}\right)$, and ii) Shampoliah farm, Fayoum Governorate (GCS 29²1'07.4"N 3044'17.8"E) (fig. 1: a, b \& c).

\section{Sampling}

Fresh samples of different medicinal plant species were collected randomly. Samples of leaves, roots, debris, and weeds were collected bimonthly for each location, from Sep 2015 to May 2016 shown in Table 1. Samples were packaged in plastic coded bags and transferred to the laboratory for extraction. Extraction by modified Tullgren funnels, individuals were collected by fine brush, mounted on modified Hoyer's media. Specimens were dried for clearing and microscope identification.

\section{Specimens confirmation}

Mite specimens recognized and confirmed by Dr. A.K. Nasr, Pests and Plant Protection Department, NRC, and Dr. A.S. Sanad, Plant Protection Research Institute, Agricultural Research Center (ARC). Insect collections were confirmed by the Entomology unit in both the Faculty of Agriculture, Cairo University, and the Pests and Plant Protection Department, NRC. Weeds were identified and confirmed by Dr. B.A. Bakry, Field Crop Department, NRC. 


\section{Statistical analysis}

The number and abundance of each species per sample were used to estimate the species richness. Biodiversity Shannon-Wiener index $\left(\mathrm{H}^{\prime}\right)$, Simpson's index (dominance D and species richness 1/D), and the similarity index between locations (Jaccard's index) were calculated for all samples using the BioDiversity Pro. ver. 2.0 software (McAleece $e t$ al., 1997) and PAST ver. 4.03 software (Hammer et al., 2001). Differences in the mean number of species within site and/or among the sites were evaluated using one-way analysis of variance (ANOVA) and were tested with Tukey's test at 95\% confidence level using SPSS computer program ver. 20.0.

To compare the similarity (and dissimilarity) between the experimental location, Jaccard index $\left(J^{\prime}\right)$ was applied following Jaccard, (1912); $\boldsymbol{S} \boldsymbol{J}=\frac{\boldsymbol{c}}{(\boldsymbol{a}+\boldsymbol{b}+\boldsymbol{c})^{\prime}}$, and the coefficient of

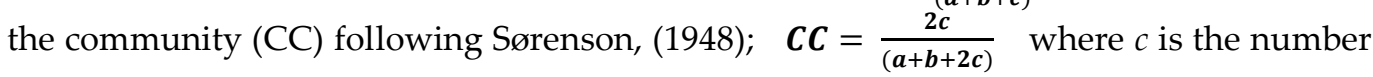
of shared species between two locations, and $a$ and $b$ are the number of species unique to each site.

\section{Results}

A Kruskal-Wallis test was conducted to detect the significant differences of the current study. Null hypothesis $H_{0}$ suggested that there is no significant differentiation of taxa diversity among selected organic locations. The alternative hypothesis $H_{1}$ was; there is significant differences in the diversity of living organisms among selected locations of the study. $H_{1}$ was accepted according to the collected sample results of the two experimental locations, there were significant impacts of fauna, flora distribution, and the diversity indices of resulted taxa.

Eleven weed species of seven families resulted in Shampoliah location (Table 2). While nine weed species belonging to six families found in SEKEM location (Table 3).

\section{Biodiversity indices and distribution in Shampoliah Farm}

The distribution of mites and insects was significant within plant samples. There were diverse groups of mites existed in Shampoliah farm; phytoseiid mites were represented by four genera, Amblyseius Berlese, 1914, Cydnoseius Muma, 1967, Phytoseius Ribaga, 1904, and Typhlodromus Scheuten, 1857. These genera presented in five predatory mite species in medicinal and weed plants. Amblyseius swirskii Athias-Henriot was in low distribution on eight plant samples $\left(s=8, \chi^{2}=194.354, T=5.000, P=0.002\right)$. The diversity indices referred to moderate abundance and species richness $\left(D=0.160,1 / D=6.250, H^{\prime}=1.931\right)$, however, it was the highest number of phytoseiid individuals found (113 specimens/samples).

The rarest species recorded was Aceria dioscorides (Soliman and Abou-Awad), found on Ploughman's spikenard Pluchea dioscoridis (L.) DC., the eriophyid mite recorded the highest dominance and richness indices, with no diversity index $(\mathrm{H})$ recorded, however, its highest number of individuals (900 specimens/ single sample, $T=1.000, P=0.332$ ). (Tables $3 \& 5)$.

The lowest dominance (D) recorded was Tydeus californicus (Banks) $=0.078$ which distributed over 14 plant samples, and different in habitat (soil, debris, leaves, and some weeds), found in few numbers (33.00 \pm 2.70 specimens/sample, $T=12.207, \chi^{2}=147.939$, $P=0.000,1 / \mathrm{D}=12.877, \mathrm{H}^{\prime}=2.588$, evenness $=0.951$ ) $($ Table 5).

The highest distribution recorded by Orius sp which collected on 15 plant samples, resulting in low dominance $(D=0.090)$ and high species richness $(1 / D)=11.121$, low diversity index $\mathrm{H}=2.443,\left(\chi^{2}=422.340, T=11.800, P=0.000\right)$ at the probability level $=95 \%$ (Table 5). Similar result was observed in $B$. tabaci $(D=0.090, \chi 2=117.534, t=6.348, P=0.000)$ distributed on 12 samples, oribatid mite species Zygoribatula syidi $(S=14, D=0.091, \chi 2=17.192$, $\mathrm{t}=6.870, P=0.000)$, acarid mite species Tyrophagous sp $(\mathrm{S}=12, \mathrm{D}=0.096, \chi 2=260.983, \mathrm{t}=8.38$, $P=0.000)$, the Collembola $(\mathrm{S}=12, \mathrm{D}=0.096, \mathrm{t}=8.352, P=0.000)$, and the mesostigmatid species 
Cosmolaelaps keni Hafez, El-Badry and Nasr ( $\mathrm{S}=13, \mathrm{D}=0.090, \chi 2=52.970, \mathrm{t}=8.308, P=0.000)$ (Tables 7,8 \& 9).

Shampoliah location has much diversity of plant species, the most diverse records of arthropods was on the nettle-leaved goosefoot $C$. murale $(S=21)$, low dominancy $(\mathrm{D}=0.106)$ highest species richness $(1 / \mathrm{D})=9.421$, highest diversity index $\mathrm{H}^{\prime}=1.092(\chi 2=1086.585$, $P=0.000$ ), A similar result in case of Slender amaranth A. viridis (Amaranthaceae), 860 individual representing 18 taxa of mite and insect species were found on the $A$. viridis habitat whether on the plant itself or in debris and soil $\left(\mathrm{H}^{\prime}=1.049, \mathrm{D}=0.114,1 / \mathrm{D}=8.783\right.$, $\chi 2=131.549, P=0.000)$. The highest distribution recorded on A. viridis in case of Cenopalpus sp (Tenuipaplidae), T. urticae (Tetranychidae) Aphis sp (Aphididae) and B. tabaci (Aleyroididae) (Tables 3, 4 \& 5).

Oppositely, the lowest arthropod distribution recorded in case of the camel-thorn $A$. maurorum (Fabaceae), only five species recorded, Laelaspis astronomicus (Koch) (Laelapidae), Z. syidi (Oribatulidae), and Collembola sp (Collembolla), and the highest dominance recorded was $(D=0.216), \chi 2=414.528$ at a probability level of $95 \%$. Fleabane $C$. aegyptiaca recorded the second lowest place in arthropod distribution, eight species representing seven families, ( 4 mite families and 3 insect families), diversity indices were significantly recorded as $\mathrm{D}=0.153,1 / \mathrm{D}=6.54, \mathrm{H}^{\prime}=0.849, \chi 2=476.887, P=0.000$ (Tables 3,4 \& 5).

\section{Biodiversity indices and distribution in SEKEM farm}

The diversity indices of arthropods in both medicinal and weed plants were significantly differed; the highest (D) value recorded in case of Egyptian crowfoot grass Dactyloctenium aegyptium (L.) Wild. (Poaceae) $(\mathrm{D}=0.388)$ representing by ten species of mites and insects, followed by the Common Cocklebur Xanthium strumarium L. (Astraceae) (D $=0.301$ ) represented by eight arthropod species, while the lowest dominance record was Salvia S. divinorum $(\mathrm{D}=0.146)$. Oppositely, Salvia recorded the highest species richness (Simpson index 1/D) which was 6.829, and the lowest was resulted in case of D. aegyptium $(1 / \mathrm{D}=2.575)$ (Tables $6 \& 7)$.

Arthropod taxa and individual distribution gave significant interactions within plant samples. In case of $L$. astronomicus $(0.81 \pm 0.23$ specimens/sample, $\mathrm{D}=0.136,1 / \mathrm{D}=7.348, \mathrm{H}=$ $\left.2.098, \chi^{2}=15.308\right)$, presented on nine plant samples in few numbers. Kleemania Oudemans 1930 , found on five plants with few numbers $(1.00 \pm 0.00$ individual/sample, $\mathrm{D}=0.200$, $\left.1 / \mathrm{D}=5.000, \mathrm{H}^{\prime}=1.609, \chi^{2}=11.000\right)$, and Collembolla Lubbock, 1871 which found on 13 samples, represented by 29 individuals $\left(\mathrm{D}=0.106,1 / \mathrm{D}=9.452, \mathrm{H}=2.384, \chi^{2}=20.103\right)$. These three genera have no significant impact within plant samples on the probability level of 95\% (Tables 8 and 9).

The heights mean number of individuals recorded was $18.13 \pm 6.67$ specimens/sample, in case of Aphis sp which found in eight samples $\left(\mathrm{D}=0.189,1 / \mathrm{D}=5.283, \mathrm{H}^{\prime}=1.828, \chi^{2}=\right.$ 588.235) at $P \leq 0.05$, T. urticae recorded $12.13 \pm 6.38$ individual/sample found in five plant leaves with few, moderate and high distribution $(\mathrm{D}=0.322,1 / \mathrm{D}=3.108, \mathrm{H}=1.292$, $\chi^{2}=804.433, P=0.000$ ).

Although, Typhlodromus sp1 (11 specimens, 4 samples), Oldealaps sp (14 specimens, 5 samples), Spinibdella sp (14 specimens, 5 samples), Amblyseius sp1 (27 specimens, 8 samples), Amblyseius sp2 (23 specimens, 6 samples), Parasitus sp ( 34 specimens, 5 samples) and Hemicheyletia wellsina (27 specimens, 6 samples) were found in few numbers and narrow distribution, but were significantly different among the whole community $\left(\chi^{2}=39.91\right.$, $38.57,86.57,39.96,48.65,141.06$, and 76.70, respectively) at $P \leq 0.05$ (Tables 8 and 9).

\section{Similarity index between experimental locations}

Jaccard index (J') and Sørenson coefficient of community (CC) were applied, where the total species recorded in the Shampoliah farm was 39 species of mite, insect, medicinal, and weed species, and SEKEM was 35 species. Shared species were 14 species, and the similarity indices were $\mathrm{J}^{\prime}=0.233$, and $\mathrm{CC}=0.378$ (Table 10). 
Few immatures belonging to Oonopidae, Simon, 1890, and only one individual of wasp spider Argiope Audouin, 1826 (Araneidae: Araneae) found during the experiment was running (Appendix). Also, ants, beetles, lacewing eggs, caterpillars, and bees were observed while sampling, but were statistically ignored.

\section{Discussion}

It is hard to find an individual species/organism within an ecosystem in nature (BBC https://www.bbc.co.uk/ bitesize/guides/zctwgdm/revision/5; Malmstrom, 2010). Simpson's index (D) measures community diversity, it's value ranges from 0 to 1 , which the larger the value, the lower the diversity (Magurran, 2013; Kiernan, 2020). It giving evidence, when an only species with no diversity; the eriophyid mite $A$. dioscorides, that found in huge numbers $(900.00 \pm 0.00, P=0.332)$ on $P$. dioscoridis. Eriophyid mites have specialization to their hosts, also, $A$. dioscorides feeding on plant tissues causes galls in the plant, these galls are considered shelters to protect the phytophagous eriophyid away from natural enemies and to guarantee maximum feeding source (Jeppson et al., 1975; Lindquist et al., 1996), so that, this would explain why this species found in huge numbers with no diversity indices.

The diversity indices $\mathrm{H}^{\prime}, \mathrm{D}$, and $1 / \mathrm{D}$ values indicating diversity within a tested location. We are usually interested not just in the biodiversity of a single site, but also in comparing biodiversity levels across sites. Also, measuring the similarity between two sites would help to understand the fraction of species they share (Magurran, 2013).

The differences in an arthropod community hypothesized that numbers, diversity, and biology may be affected by different impacts such; host plant nutritional contents, morphological, and domatia structure of organic plant cultivars (Akyazı et al., 2021; AbouElella et al., 2021). It should be noted that a single factor is not responsible for the abundance and diversity of arthropods but the combination of factors. Since the effect of cultivars on the mite population is time-consuming, such results caould only observed in the long term (Camporese and Duso, 1996; Krips et al., 1999; Kretier et al., 2002; Ali et al., 2015).

It was noticed that old organic farms are characterized by fewer individuals and taxa than young ones. It was suggested that arthropod communities in the old system, reached their maximum balance, the abundance of specimens and biodiversity tended to be lower than in the younger systems. To accept this hypothesis, it is required to have more information about soil nutrient analysis, plant-arthropod relations, farming systems, and biogeographical distribution (Simoni et al., 2013).

Spontaneous plants have wide dispersal and common distribution in all eco-systems (Neto et al., 2015; Deghiche-Diab et al., 2016; 2020), but do they consider pests for crops? Weeds are good habitat for predacious species (Valdes, 2016), some researchers studied how weeds could be a good refuge for predators, however, they are carrying various phytophagous pests (less in importance), this mini-environment called the "Banker plant" (Parolin et al., 2001 and 2002; Xiao et al., 2012).

To accept this hypothesis, we measured the diversity indices of weeds; which are shared among two locations. Cheese weed $M$. parviflora, has the highest species diversity indices in SEKEM $\left(S=16\right.$, total individuals $=307$ individuals, $D=0.217,1 / D=4.614, H^{\prime}=$ 0.788) (Table 7), while the nettle leaf goosefoot $C$. murale was the highest in Shampoliah $\left(S=21\right.$, total individuals $=799$ individuals, $\left.\mathrm{D}=0.106,1 / \mathrm{D}=9.421, \mathrm{H}^{\prime}=1.092\right)$ (Table 4) (fig. 2). These plants were rich in their arthropod community; however, their trophic group, either predator or phytophagous species was recorded, but the density of populations were not the same (Tables $3 \& 8$ ). Also, their distribution along experimental cites borders and overlapping with the medicinal crops, would definitely help increasing the arthropod distribution that measured (Appendix). Similar indices of A. viridis, P. major in both locations of our study, were resulted in case of Quinoa Chenopodium quinoa Willd. (Deghiche-Diab et al., 2021), and the findings of Bennet and Garton (2013), and Deghiche-Diab et al., (2016 \& 2020). 
The study hypothesized understanding the Arthropod-Plant interactions; which suggested based on soil fertilization effect. Using organic fertilizers (manure) could adjust the available micronutrients by changing both physical and biological characteristics of either the plant or the soil; organic fertilization increasing P levels in soil, which caused an increase in protein, K, Fe, Mn, and Zn in plant contents (Zeidan and EL Kramany, 2001; Zeidan, 2007; Zeidan et al., 2010), which led to increasing in mite diversity (Abo-Shnaf et al., 2016). Plants in the organic systems have better predacious mite species richness and distribution (El-Banhawy et al., 1998). Plant size; the hypothesis suggested that large sized plants are more attractive for correlative species richness of arthropods (predacious or phytophagous) than smaller plants (Schlinkert et al., 2015).

Although, there is several Egyptian literatures dealt with insect, mite, and spider species biodiversity, but these studies do not discuss the actual plant-arthropod relations, neither di-trophic (plant-herbivore) nor tri-trophic (plant-predator-herbivore) relations. Interactions been also suggested; the plant responds to phytophagous activities, by producing volatiles that attract predators (McCormick et al., 2012). Also, duo to plant morphological characters (Lawton, 1983). Some changes in Nitrogen contents with ammonium nitrate stimulated the fecundity of the whitefly $B$. tabaci, which attracted more individuals to oviposit on treated plants. Nitrogen fertilization may decrease plant resistance to insect pests by improving the nutritional quality of host plants and reducing the secondary metabolite concentrations (Bentz et al., 1995; Yardım and Edwards, 2003). Nutritional contents of plants in organic ecosystems have positively increased. Increasing in Nitrogen (N), Phosphor (P), Potassium (K), Sodium (Na), and Calcium (Ca), had significantly affect the life table parameters and biological behaviors of T. urticae, which may reflect on the prey-predator relations (Ali et al., 2015; Abou-Elella et al., 2021).

\section{Conclusion}

In conclusion, there are many examples in the literature where the amount and configuration of natural/organic and semi-natural biodiversity in agro-ecosystems could help to enhance pest control and reduce the probabilities of pest outbreaks. In the current study we could proposed explanations for the faunal and floral diversification. The added hypothesis; is to show that the relative importance of natural habitat (organic ecosystems) is supporting natural enemies and natural pest control, which could vary dramatically with the type of crop, pest species, habitat, management designed, and landscape type considered. The Shannon-Wiener $\left(H^{\prime}\right)$, and Simpson (D and $\left.1 / D\right)$ values indicating diversity within a tested location. We are interested not just in the biodiversity of a single site, but also in comparing biodiversity levels across sites. Also, measuring the similarity/dissimilarity between experimental sites, which helps to understand the fraction of species they share. A further study needed to detect the climate change impacts through 5-10 years in the same tested locations, to find if the population structure, taxa variability, and the biodiversity indices had changed.

\section{Disclosure}

Funding: This study has funded by The National Research Centre (NRC).

Conflicts of interest: The authors declare that they have no conflict of interest.

Acknowledgments: The authors are like to express their deep gratitude and respect to Prof. Abdel Rady K. Nasr, Pests and Plant Protection Department, NRC, and Dr. Ahmed S. Sanad, Plant Protection Research Institute, Agricultural Research Center (ARC), for their help in mites group identification. Thanks are due to Dr. Bakry A. Bakry, Field Crop Dept., NRC for identifying and confirming the weed collections. Thanks also due to SEKEM, and the Association of Small Crops and Biological Products (Kamal Shampoliah) management for their help while this study was running. 


\section{References}

Abd El-Karim HS, Rahil AA, Rizk MA (2016). The difference between organic and conventional cultivation on biodiversity activity of spiders (Araneae) in chamomile and chrysanthemum in Fayoum Governorate, Egypt. Egyptian Academic Journal of Biological Sciences A. Entomology. 9(4): 83-95. https://www.doi.org/10.21608/EAJBSA.2016.12753

Abo Shnaf RI, Romeih AM, Allam SF (2008). Biodiversity of mites associated with parrots and peacocks in Giza Zoo, Egypt. Acarines. 2(1): 27-30. https://doi.org/10.21608/ajesa.2008.4975

Abo-Shnaf RI, Zaki AY, Aly AI, Mergawy M (2016). Effect of different fertilization treatments on the biodiversity of mites associated with tomato plants and its yield in Fayoum Governorate, Egypt. Acarines. 10(1): 25-29. https://doi.org/10.21608/ajesa.2016.164048

Abou-Elella GM, Hassan MF, Elsaeidy EMAK, Nawar MS \& Zidan IM (2021). How organic medicinal plants affect life table parameters of Tetranychus urticae (Acari: Tetranychidae)? Persian Journal of Acarology, 10(1): 69-83. https://www.doi.org/10.22073/pja.v10i1.59623

Adam M, Heuer H, Ramadan E, Hussein M, Hallmann J (2013). Occurrence of plant-parasitic nematodes in organic farming in Egypt. International Journal of Nematology. 23(1): 82-90.

Akyazı R, Welbourn C, Liburd OE (2021). Mite species (Acari) on blackberry cultivars in organic and conventional farms in Florida and Georgia, USA. Acarologia, 61(1): 31-45. https://doi.org/10.24349/acarologia/20214414

Ali FS, Afifi AM, ElSaiedy EMA, Ahmed MM (2015). Effect of phytochemical components, morphological and histological leaf structure of five tomato hybrids on Tetranychus urticae Koch Infestation. Acarines, 9: 23-30. https://doi.org/10.21608/AJESA.2015.163978.

Alistair D, Galloway CL, Seymour RG, James S (2021). Organic farming promotes arthropod predators, but this depends on neighbouring patches of natural vegetation. Agriculture, Ecosystems and Environment. 310: 107295. https://doi.org/10.1016/j.agee.2020.107295

Bengtsson J, Ahnström J, Weibull A (2005). The effects of organic agriculture on biodiversity and abundance: A meta-analysis. Journal of Applied Ecology. 42(2): 261 - 269. https://doi.org/10.1111/j.1365-2664.2005.01005.x

Bennett A, Gratton C (2013). Floral diversity increases beneficial arthropod richness and decreases variability in arthropod community composition. Ecological Applications. 23(1), 86-95. http://www.jstor.org/stable/23440819

Camporese P, Duso C. 1996. Different colonization patterns of phytophagous and predatory mites (Acari,Tetranychidae, Phytoseiidae) on three grape varieties, A case study. Experimental and Applied Acarology. 20 : 122. https://www.doi.org/10.1007/s10493-012-9519-z

Deghiche-Diab N, Deghiche L, Belhamra M (2020). Study of spontaneous plants and their associated arthropods in Ziban oases agroecosystem, Biskra-Algeria. IOBC-WPRS Bulletin, 151: 127-134.

Deghiche-Diab N, Deghiche L, Kachai S (2016). Importance of spontaneous plants of steppe arid regions Ouled Djellel Biskra (Algeria) International Journal of Botany Studies, 1(3): 3-7.

Deghiche-Diab N, Fraih A, Deghiche L, Tarai N (2021). Biodiversity and ecological studies of arthropods associated to Quinoa (Chenopodium quinoa Willd.) in Biskra region. Munis Entomology \& Zoology, 16 (1): 427-434. (Available at https://www.researchgate.net/publication/348077273).

El-Sanady M, Mohamed A (2013). Biodiversity and seasonal abundance of mites associated with two varieties of date palm in Giza and Sohag Governorates, Egypt. Acarines. 7(2): 57-62. https://doi.org/10.21608/ajesa.2013.163737.

El-Sheikh WEA, El-Kenway AH, Soliman MM (2020). Biodiversity and population dynamics of natural enemies in the Western Desert Agro-Ecosystem, Egypt. Egyptian Academic Journal of Biological Sciences A. Entomology. 13(4):1-14. https://www.doi.org/10.21608/EAJBSA.2020.116977

FiBL (2021). The World of Organic Agriculture 2021. https://www.organic-world.net/yearbook/yearbook-2021/presentations.html

Gardarin A, Plantegenest M, Bischoff A, Valantin-Morison M (2018). Understanding plant-arthropod interactions in multitrophic communities to improve conservation biological control: useful traits and metrics. Journal of Pest Science. 91: 943-955. https://doi.org/10.1007/s10340-018-0958-0

Hammer $\varnothing$, Harper DAT, Ryan PD (2001). PAST: Paleontological statistics software package for education and data analysis. Palaeontologia Electronica, 4(1): 1-9. Available at https://palaeo-electronica.org/2001_1/past/issue1_01.htm

Imam AI, Sawaby RF (2013 a). Arthropod diversity associated with infestation spots of fig tree borer under rain-fed conditions of Maged valley, Matrouh, Egypt. Egyptian Academic Journal of Biological Sciences A. Entomology. 6(3): 11 -19. https://www.doi.org/10.21608/EAJBSA.2013.13224

Imam AI, Sawaby RF (2013 b). Diversity of arthropod harbored Mitnan, Thymelaea hirsute, shrub under rain-fed conditions of Habbes valley, Matrouh, Egypt. Egyptian Academic Journal of Biological Sciences A. Entomology. 6(3): 39 -47. https://www.doi.org/10.21608/EAJBSA.2013.13229

Kiernan D (2020). Natural resources. https://stats.libretexts.org/ 
Kreiter S., Tixier M.S., Croft A., Auger P., Barret D. (2002). Plants and leaf characteristics influencing the predaceous mite Kampimodromus aberrans (Acari, Phytoseiidae) in habitats surrounding vineyards. Environmental Entomology. 31(4): 648-660. https://www.doi.org.10.1603/0046-225X-31.4.648.

Krips O.E., Kleijn P.W., Willems P.E.L., Gols G.J.Z., Dicke M. (1999). Leaf hairs influence searching efficiency and predation rate of the predatory mite Phytoseiulus persimilis (Phytoseiidae, Acarina). Experimental and Applied Acarology. 23(2): 119131. https://doi.org/10.1023/A:1006098410165.

Lawton JH (1983). Plant architecture and the diversity of phytophagous insects. Annual Review of Entomology 28(1): 23-39. https://doi.org/10.1146/annurev.en.28.010183.000323

Magurran AE. (2013). Measuring biological diversity. John Wiley \& Sons. ISBN: 978-1-118-68792-5. [Accessed May 23, 2021, Magurran: Measuring biological diversity - Google Scholar]

Malmstrom, C. (2010) Ecologists study the interactions of organisms and their environment. Nature Education Knowledge. 3(10):88 (Available at https://www.nature.com/scitable/knowledge/library/ecologists-study-the-interactions-of-organisms-and13235586/)

Marselle MR, Hartig T, Cox DTC, de Bell S, Knapp S, Lindley S, Triguero-Mas M, Böhning-Gaese K, Braubach M, Cook PA, de Vries S, Heintz-Buschart A, Hofmann M, Irvine KN, Kabisch N, Kolek F, Kraemer R, Markevych I, Martens D, Müller R, Nieuwenhuijsen M, Potts JM, Stadler J, Walton S, Warber SL, Bonn A. (2021). Pathways linking biodiversity to human health: A conceptual framework. Environment International, 150: 106420. https://doi.org/10.1016/j.envint.2021.106420.

McAleece N, Gage JDG, Lambshead PJD, Paterson GLJ (1997). Biodiversity professional statistics analysis software. Scottish Association for Marine Science and the Natural History Museum London. 2 pp. Available at http://www.sams.ac.uk/peterlamont/biodiversity-pro\#sthash.I2R3telW.dpuf

McCormick AC, Unsicker SB, Gershenzon J (2012). The specificity of herbivore-induced plant volatiles in attracting herbivore enemies. Trends in Plant Science. 17(5): 303-310. https://doi.org/10.1016/j.tplants. 2012.03.012.

Montañez, MN, Amarillo-Suárez Á. (2014). Impact of organic crops on the diversity of insects: a review of recent research. Revista Colombiana de Entomología, 40(2): 131-142. [Available at http://www.scielo.org.co/pdf/rcen/v40n2/v40n2a01.pdf]

Neto AMO, Rocha FC, Bottega EL, Guerra N, Rocha RP, Vilar CC (2015). Weed mapping using techniques of precision agriculture. Planta Daninha, 33(1): 157-164.

Parolin P, Bresch C, Desneux N, Brun R, Bout A, Boll R, Poncet C (2012). Secondary plants used in biological control: A review. International Journal of Pest Management, 58(2): 91-100.

Parolin P, Bresch C, Ruiz G, Desneux N, Poncet C (2013). Testing banker plants for biological control of mites on roses. Phytoparasitica, 41: 249-262.

Phillips D, Lindquist M. (2021). Just weeds? Comparing assessed and perceived biodiversity of urban spontaneous vegetation in informal greenspaces in the context of two American legacy cities. Urban Forestry \& Urban Greening, 62: 127151, https://doi.org/10.1016/j.ufug.2021.127151.

Rizk MA; Mikhail WZA; Ghallab MM; Zaki AY; Habashi NH; Iskander AKF. (2017). The effect of agricultural practices on the abundance and biodiversity of soil fauna: A Review. Egyptian Academic Journal of Biological Sciences A. Entomology. 10(7): 357-376. https://www.doi.org/10.21608/EAJB.2017.12121

Sallam G, Abdel-Aziem N, El-Kawas H (2010). Biodiversity of spiders associated with cotton and maize in Sharkia Governorate with a special reference to the spider, Kochiura aulica (Koch). Acarines. 4(1): 67-71. https://doi.org/10.21608/ajesa.2021.163547

Sawaby RF, El-Hamouly H, Nasser MG. (2010). Pilot study of population density and biodiversity index of Mantodea fauna in ElFayoum governorate- Egypt. Egyptian Academic Journal of Biological Sciences A. Entomology. 3 (2): 19 - 26. https://www.doi.org/10.21608/EAJBSA.2010.15184.

Schlinkert H, Westphal C, Clough Y, László Z, Ludwig M, Tscharntke T (2015). Plant Size as Determinant of Species Richness of Herbivores, Natural Enemies and Pollinators across 21 Brassicaceae Species. PLoS ONE 10(8): e0135928. https://www.doi.org/10.1371/journal.pone.0135928

Siam G, Abdelhakim T. (2019). The organic agriculture in Egypt. [Research Report] CIHEAM-IAMM. 2019, pp.37. [Available at https://hal.archives-ouvertes.fr/hal-02137639; Accessed Mar 31, 2021, CAI, EGY].

Simoni S, Nannelli R, Castagnoli M, Goggioli D, Moschini V, Vazzana C, Benedettelli S, Migliorini P. (2013). Abundance and biodiversity of soil arthropods in one conventional and two organic fields of maize in stockless arable systems. REDIA. XCVI. 37-44.

Tropek R, Kadlec T, Karesova P, Spitzer L, Kocarek P, Malenovsky I, Banar P, Tuf I, Hejda M, Konvicka, M. (2010). Spontaneous succession in limestone quarries as an effective restoration tool for endangered arthropods and plants. Journal of Applied Ecology. 47. 139 - 147. https://doi.org/10.1111/j.1365-2664.2009.01746.x

Underwood T, McCullum-Gomez C, Harmon A, Roberts S. (2011). Organic Agriculture Supports Biodiversity and Sustainable Food Production. Journal of Hunger \& Environmental Nutrition. 6: 398-423. https://www.doi.org/10.1080/19320248.2011.627301

Zaki AY (2021). Diversity and abundance of spider and other soil animals as influenced by fertilization and their effect on yield of onion at Fayoum Governorate, Egypt. Acarines. (In Press). https://doi.org/10.21608/ajesa.2021.16356.1016. 
Zaki AY, Abo-Shnaf RI (2018). Soil mites inhabiting chamomile and marigold plants under two different cultivations at Fayoum governorate. Acarines. 12 (1): 75-79. http://doi.org/10.21608/AJESA.2008.164302

Zaki AY, Aly AI (2018). Biodiversity of spider and other arthropods inhabiting cowpea under effect of fish culture water and nitrogen fertilization and its yield, protein at Fayoum Governorate. Acarines. 12(1): 87-98. https://doi.org/10.21608/ajesa.2008.164305

Zaki AY, Aly AI (2019). Diversity and abundance of spider and other soil animals as influenced by fertilization and their effect on yield of onion at Fayoum Governorate, Egypt. Acarines. 13(1): 57-72. https://doi.org/10.21608/ajesa.2019.164157

Zaki AY, Aly AI, Eid RA, Mergawy MM (2015). Biodiversity of ground spiders (Araneae) occurred in tomato and tomato yield fertilized with different organic manures in Fayoum Governorate. Egyptian Academic Journal of Biological Sciences A. Entomology. 8(3): 87-96. https://www.doi.ogr/10.21608/EAJBSA. 2015.12872 
Table 1. Samples of the medicinal plants collected of the experimental organic locations.

\begin{tabular}{|c|c|c|c|c|}
\hline Plant name & Scientific name & Family & Sampling parts & Location \\
\hline Moringa & Moringa oleifera Lam. & Moringaceae & leaves, weeds, debris, soil & 2 \\
\hline Pot marigold & Calendula officinalis & \multirow{2}{*}{ Asteraceae } & leaves, weeds, debris, soil & 1,2 \\
\hline Chamomile & Chamaemelum nobile (L.) All. & & leaves, weeds, debris, soil & 1,2 \\
\hline Lemongrass & Cymbopogon schoenanthus (L.) Spreng. & Poaceae & leaves, weeds, debris, soil & 2 \\
\hline Sage & Salvia officinalis L. & \multirow{5}{*}{ Lamiaceae } & leaves, weeds, debris, soil & 2 \\
\hline Basil & Ocimum basilicum $\mathrm{L}$. & & Total herb, weeds & 2 \\
\hline Spearmint & Mentha spicata $\mathrm{L}$. & & Total herb, weeds, debris, soil & 1 \\
\hline Saudi mint & M. officinalis L. & & Total herb, weeds, debris, soil & 1 \\
\hline Rosemary & Rosmarinus officinalis $\mathrm{L}$ & & Total herb, weeds, debris, soil & 1 \\
\hline
\end{tabular}

1: Shampoliah, and 2: SEKEM

Table 2. Weed species of Shampoliah farm.

\begin{tabular}{|c|c|c|c|c|}
\hline \multicolumn{2}{|c|}{ Weeds } & \multirow{2}{*}{ Family } & \multicolumn{2}{|c|}{ Geographic Coordinate System (GCS) } \\
\hline Common Name & Scientific name & & Latitude & Longitude \\
\hline Camelthron & Alhagi maurorum Medic. & Fabaceae & $29^{\circ} 21^{\prime} 04.9^{\prime \prime} \mathrm{N}$ & $30^{\circ} 44^{\prime} 24.7 " \mathrm{E}$ \\
\hline Pigweed & Amaranthus cruentus L. & Amaranthaceae & $29^{\circ} 21^{\prime} 04.6^{\prime \prime} \mathrm{N}$ & $30^{\circ} 44^{\prime} 23.8^{\prime \prime} \mathrm{E}$ \\
\hline Slender amaranth & Amaranthus viridis $\mathrm{L}$. & Amaranthaceae & $29^{\circ} 21^{\prime} 04.6^{\prime \prime} \mathrm{N}$ & $30^{\circ} 44^{\prime} 23.8^{\prime \prime} \mathrm{E}$ \\
\hline Spanish needles & Bidens biponnata $\mathrm{L}$. & Asteraceae & $29^{\circ} 21^{\prime} 03.5^{\prime \prime} \mathrm{N}$ & $30^{\circ} 44^{\prime} 31.1 " \mathrm{E}$ \\
\hline Shepherd's purse & Capsella bursa-pastoris (L.) Medik. & Brassicaceae & $29^{\circ} 20^{\prime} 59.6^{\prime \prime} \mathrm{N}$ & $30^{\circ} 44^{\prime} 27.2^{\prime \prime} \mathrm{E}$ \\
\hline Nettle-leaved goosefoot & Chenopodium murale $\mathrm{L}$. & Amaranthaceae & $29^{\circ} 21^{\prime} 03.5^{\prime \prime} \mathrm{N}$ & $30^{\circ} 44^{\prime} 31.1^{\prime \prime} \mathrm{E}$ \\
\hline Fleabane & Conyza aegyptiaca (L.) Aiton. & Asteraceae & $29^{\circ} 21^{\prime} 00.1^{\prime \prime} \mathrm{N}$ & $30^{\circ} 44^{\prime} 33.4^{\prime \prime} \mathrm{E}$ \\
\hline Cheese weed & Malva parviflora $\mathrm{L}$ & Malvaceae & $29^{\circ} 20^{\prime} 59.6^{\prime \prime} \mathrm{N}$ & $30^{\circ} 44^{\prime} 27.2^{\prime \prime} \mathrm{E}$ \\
\hline Broadleaf plantain & Plantago major L. & Plantaginaceae & $29^{\circ} 20^{\prime} 57.3^{\prime \prime} \mathrm{N}$ & $30^{\circ} 44^{\prime} 16.6^{\prime \prime} \mathrm{E}$ \\
\hline Ploughman's spikenard & Pluchea dioscoridis (L.) DC. & Asteraceae & $29^{\circ} 21^{\prime} 05.4^{\prime \prime} \mathrm{N}$ & $30^{\circ} 44^{\prime} 26.5^{\prime \prime} \mathrm{E}$ \\
\hline Giant pigweed & Trianthema portulacastrum $\mathrm{L}$. & Aizoaceae & $29^{\circ} 21^{\prime} 04.9^{\prime \prime} \mathrm{N}$ & $30^{\circ} 44^{\prime} 24.7^{\prime \prime} \mathrm{E}$ \\
\hline Common Cocklebur & Xanthium strumarium L. & Asteraceae & $29^{\circ} 21^{\prime} 00.1^{\prime \prime} \mathrm{N}$ & $30^{\circ} 44^{\prime} 33.4^{\prime \prime} \mathrm{E}$ \\
\hline
\end{tabular}

Table 3. Abundance and distribution of the Arthropod species at Shampoliah farm plants.

\begin{tabular}{|c|c|c|c|c|c|c|c|c|c|c|c|c|c|c|c|c|c|c|}
\hline \multicolumn{2}{|r|}{ Taxa } & \multicolumn{17}{|c|}{$\begin{array}{c}\text { Samples } \\
\end{array}$} \\
\hline Family & Genera/Species & $\mathrm{Sp}$ & $\mathrm{C}$ & $\mathrm{Ch}$ & SM & $\mathbf{B}$ & CHW & PIS & CT & PW & SA & SPN & SHP & N1G & $\mathbf{F}$ & B1P & HoP & $\mathrm{CC}$ \\
\hline \multirow{5}{*}{ Phytoseiidae } & Amblyseius swirskii & & & + & & + & + & + & & & + & & & + & & + & + & \\
\hline & Cydnoseius negevi & & & & + & & + & & & + & + & & & + & & + & & + \\
\hline & Typhlodromus sp. & & & + & & & + & & & + & & & & + & + & & + & + \\
\hline & Amblyseius sp. & + & + & & + & & & + & & & + & & & + & & + & & + \\
\hline & Phytoseius finitimus & & & & & + & + & ++ & & + & & & + & + & & + & & \\
\hline Macrochelidae & Macrocheles sp. & & + & + & & + & + & + & & & + & & + & + & + & + & & \\
\hline \multirow{2}{*}{ Laelapidae } & Cosmolaelaps keni & & & + & + & + & + & + & & & + & + & + & + & + & + & + & + \\
\hline & Laelaspis astronomicus & & + & & & & & & + & & & & + & + & & & + & + \\
\hline Tenuipalpidae & Cenopalpus sp. & ++ & + & + & +++ & +++ & & + & & ++ & +++ & + & + & ++ & & & & ++ \\
\hline \multirow{2}{*}{ Tetranychidae } & Tetranychus urticae & ++ & ++ & & ++ & ++ & +++ & & & +++ & +++ & & & +++ & & ++ & & ++ \\
\hline & Oligonyghus aferstiacus & & & + & + & +++ & & + & & & ++ & ++ & +++ & +++ & & & +++ & + \\
\hline Stigmaeidae & Agestimus exsertus & & + & + & + & & + & + & & + & + & + & + & + & & + & & + \\
\hline Tydeidae & Tydeus californicus & + & + & + & + & + & + & + & & + & + & + & + & + & & + & + & \\
\hline Eriophyidae & Aceria dioscorides & & & & & & & +++ & & & & & & & & & & \\
\hline Oribalutidae & Zygoribatula syidi & + & & & & + & + & + & + & + & + & + & + & + & + & + & + & + \\
\hline Acaridea & Rhizogliphus robini & & ++ & & + & & & & + & & + & ++ & + & + & + & + & ++ & \\
\hline Acaridea & Tyrophagus putrescentiae & + & & + & + & + & & + & + & + & ++ & & + & ++ & & + & ++ & \\
\hline Aphididae & Aphis sp. & & ++ & & ++ & & +++ & & & ++ & +++ & ++ & & ++ & & +++ & & +++ \\
\hline Aleyroididae & Bemisia tabaci & ++ & ++ & & & ++ & ++ & + & & & +++ & & ++ & ++ & + & ++ & ++ & ++ \\
\hline Anthocoridae & Orius sp. & + & & + & + & + & + & + & & + & + & + & + & + & + & + & + & + \\
\hline Thripidae & Thrips tabaci & & + & + & & + & ++ & & & + & ++ & & & + & & + & ++ & +++ \\
\hline Collembola & Collembola & + & + & & + & & + & + & + & & + & & + & + & + & & + & + \\
\hline
\end{tabular}

(+) low distribution 1-45, (++) moderate distribution 46-90, (+++) common species >90. Sp: Spearmint, C: Calindula, Ch: Chamomile, SM: Saudi mint, B: Basil, CHW: Cheeseweed, P1S: Ploughmans spikenard, CT: Camelthron, PW: Pigweed, SA: Slender Amaranth, SPN: Spanish needles, SHP: Shepherd's Purse, NIG: Nettle-leaved goosefoot, F: Fleabane, BIP: Broadleaf Plantain, HoP: Horse Purslane, CC: Common Cocklebur. 
Table 4. Diversity indices of medicinal and weed plants at Shampoliah farm.

\begin{tabular}{|c|c|c|c|c|c|c|c|}
\hline Sample & $S$ & $\begin{array}{c}\text { Total } \\
\text { individuals }\end{array}$ & Mean/ 10 samples \pm SE & $\mathbf{H}^{\prime}$ & (D) & (1/D) & $\chi^{2}$ \\
\hline Spearmint & 9 & 283 & $12.86 \pm 5.21 \mathrm{e}$ & 0.764 & 0.199 & 5.022 & $974.421^{*}$ \\
\hline Calendula & 12 & 381 & $17.32 \pm 5.78 \mathrm{~d}$ & 0.899 & 0.149 & 6.695 & $889.745^{*}$ \\
\hline Chamomile & 11 & 160 & $7.27 \pm 2.22 \mathrm{f}$ & 0.938 & 0.129 & 7.766 & $312.450^{*}$ \\
\hline Saudi mint & 13 & 412 & $18.73 \pm 6.56 \mathrm{~d}$ & 0.918 & 0.161 & 6.226 & $1062.214^{*}$ \\
\hline Basil & 13 & 553 & $25.14 \pm 8.01 \mathrm{c}$ & 0.950 & 0.141 & 7.108 & $1177.521^{*}$ \\
\hline Cheese weed & 15 & 644 & $29.27 \pm 10.65 \mathrm{c}$ & 0.928 & 0.171 & 5.862 & $1791.304^{*}$ \\
\hline Ploughman's spikenard & 15 & 1230 & $55.91 \pm 40.32 \mathrm{a}$ & 0.543 & 0.541 & 1.847 & $13433.018^{*}$ \\
\hline Camelthorn & 5 & 106 & $4.82 \pm 2.08 \mathrm{~g}$ & 0.674 & 0.216 & 4.634 & $414.528^{*}$ \\
\hline Pigweed & 12 & 478 & $21.73 \pm 7.43 \mathrm{c}$ & 0.918 & 0.155 & 6.437 & $1174.209^{*}$ \\
\hline Slender Amaranth & 18 & 860 & $39.09 \pm 10.54 b$ & 1.049 & 0.114 & 8.783 & $1313.549^{*}$ \\
\hline Spanish needles & 9 & 300 & $13.64 \pm 5.04 \mathrm{e}$ & 0.820 & 0.172 & 5.823 & $851.627^{*}$ \\
\hline Shepherd's Purse & 14 & 487 & $22.17 \pm 7.25 \mathrm{c}$ & 0.959 & 0.146 & 6.851 & $1095.690^{*}$ \\
\hline Nettle-leaved goosefoot & 21 & 799 & $36.32 \pm 9.42 b$ & 1.092 & 0.106 & 9.421 & $1086.585^{*}$ \\
\hline Fleabane & 8 & 194 & $8.82 \pm 3.02 \mathrm{f}$ & 0.849 & 0.153 & 6.544 & $476.887^{*}$ \\
\hline Broadleaf Plantain & 16 & 564 & $25.64 \pm 9.40 \mathrm{c}$ & 0.944 & 0.172 & 5.804 & $1592.156^{*}$ \\
\hline Horse Purslane & 13 & 437 & $19.86 \pm 6.08 \mathrm{~d}$ & 0.939 & 0.133 & 7.521 & $860.396^{*}$ \\
\hline Common Cocklebur & 15 & 612 & $27.82 \pm 8.05 \mathrm{c}$ & 0.997 & 0.124 & 8.062 & $1077.327^{*}$ \\
\hline
\end{tabular}

Table 5. Diversity indices and analysis of variances of arthropod species at Shampoliah farm.

\begin{tabular}{|c|c|c|c|c|c|c|c|c|c|c|}
\hline Species & Taxa $(S)$ & Total individuals & Mean/10 samples $\pm \mathrm{SE}$ & D & 1/D & $\left(\mathrm{H}^{\prime}\right)$ & Evenness & $\chi^{2}$ & T-value & $P$ \\
\hline Amblyseius swirskii & 8 & 113.00 & $14.13 \pm 2.82 \mathrm{e}$ & 0.160 & 6.250 & 1.931 & 0.862 & 194.354 & 5.000 & 0.002 \\
\hline Cydnoseius negevi & 7 & 102.00 & $14.57 \pm 1.31 \mathrm{e}$ & 0.150 & 6.676 & 1.922 & 0.976 & 157.667 & 11.151 & 0.000 \\
\hline Typhlodromus sp. & 7 & 80.00 & $11.43 \pm 2.26 \mathrm{e}$ & 0.176 & 5.672 & 1.812 & 0.875 & 159.700 & 5.066 & 0.002 \\
\hline Amblyseius sp. & 8 & 50.00 & $6.25 \pm 1.73 \mathrm{f}$ & 0.192 & 5.208 & 1.834 & 0.783 & 113.200 & 3.614 & 0.009 \\
\hline Phytoseius finitimus & 7 & 110.00 & $15.71 \pm 5.04 \mathrm{e}$ & 0.231 & 4.327 & 1.709 & 0.789 & 322.109 & 3.117 & 0.021 \\
\hline Macrocheles sp. & 10 & 50.00 & $5.00 \pm 1.17 \mathrm{f}$ & 0.150 & 6.684 & 2.050 & 0.777 & 77.160 & 4.260 & 0.002 \\
\hline Cosmolaelaps keni & 13 & 99.00 & $7.62 \pm 0.92 \mathrm{f}$ & 0.090 & 11.074 & 2.465 & 0.905 & 52.970 & 8.308 & 0.000 \\
\hline $\begin{array}{c}\text { Laelaspis } \\
\text { astronomicus }\end{array}$ & 6 & 44.00 & $7.33 \pm 1.73 \mathrm{f}$ & 0.213 & 4.699 & 1.667 & 0.883 & 115.182 & 4.250 & 0.008 \\
\hline Cenopalpus sp. & 12 & 750.00 & $62.50 \pm 10.34 c$ & 0.108 & 9.225 & 2.326 & 0.853 & 632.168 & 6.047 & 0.000 \\
\hline Tetranychus urticae & 10 & 1131.00 & $113.10 \pm 18.60 \mathrm{~b}$ & 0.124 & 8.045 & 2.185 & 0.889 & 1259.747 & 6.080 & 0.000 \\
\hline $\begin{array}{c}\text { Oligonyghus } \\
\text { aferstiacus }\end{array}$ & 10 & 724.00 & $72.40 \pm 14.01 \mathrm{c}$ & 0.134 & 7.479 & 2.132 & 0.843 & 921.619 & 5.168 & 0.001 \\
\hline Agestimus exsertus & 12 & 240.00 & $20.00 \pm 3.45 \mathrm{e}$ & 0.111 & 9.042 & 2.286 & 0.820 & 211.208 & 5.799 & 0.000 \\
\hline Tydeus californicus & 14 & 462.00 & $33.00 \pm 2.70 \mathrm{~d}$ & 0.078 & 12.877 & 2.588 & 0.951 & 147.939 & 12.207 & 0.000 \\
\hline Aceria dioscorides & 1 & 900.00 & $900.00 \pm 0.00 \mathrm{a}$ & 1.000 & 1.000 & 0.000 & 1.000 & $14.000^{\mathrm{ns}}$ & $1.000^{\mathrm{ns}}$ & 0.332 \\
\hline
\end{tabular}




\begin{tabular}{ccccccccccc}
\hline \multicolumn{10}{c}{ Table 5. Cont. } \\
\hline Species & Taxa (S) & $\begin{array}{c}\text { Total } \\
\text { individuals }\end{array}$ & $\begin{array}{c}\text { Mean/10 samples } \pm \\
\text { SE }\end{array}$ & $\mathbf{D}$ & 1/D & (H') & Evenness & $\chi^{2}$ & T-value & $\boldsymbol{P}$ \\
\hline $\begin{array}{c}\text { Zygoribatula syidi } \\
\text { Rhizogliphus robini }\end{array}$ & 14 & 250.00 & $17.86 \pm 2.60 \mathrm{e}$ & 0.091 & 10.977 & 2.478 & 0.851 & 137.192 & 6.870 & 0.000 \\
Tyrophagus & 10 & 376.00 & $37.60 \pm 5.08 \mathrm{~d}$ & 0.116 & 8.591 & 2.215 & 0.917 & 368.112 & 7.405 & 0.000 \\
putrescentiae & 12 & 409.00 & $34.08 \pm 4.06 \mathrm{~d}$ & 0.096 & 10.378 & 2.404 & 0.922 & 260.983 & 8.389 & 0.000 \\
Collembola & 12 & 154.00 & $12.83 \pm 1.54 \mathrm{e}$ & 0.096 & 10.366 & 2.406 & 0.924 & 98.571 & 8.352 & 0.000 \\
Aphis sp. & 9 & 945.00 & $105.00 \pm 15.28 \mathrm{~b}$ & 0.130 & 7.698 & 2.119 & 0.925 & 1142.330 & 6.873 & 0.000 \\
Thrips tabaci & 10 & 489.00 & $48.90 \pm 7.64 \mathrm{~d}$ & 0.122 & 8.203 & 2.190 & 0.894 & 524.708 & 6.404 & 0.000 \\
Bemisia tabaci & 12 & 799.00 & $66.58 \pm 5.64 \mathrm{c}$ & 0.090 & 11.121 & 2.443 & 0.959 & 422.340 & 11.800 & 0.000 \\
Orius sp. & 15 & 223.00 & $14.87 \pm 2.34 \mathrm{e}$ & 0.090 & 11.132 & 2.532 & 0.838 & 117.534 & 6.348 & 0.000 \\
\hline
\end{tabular}

Chi square $\left(\chi^{2}\right)$ values are significant at $P \leq 0.05, \mathrm{df}=16$

The means followed by similar letters are not significantly different (Tukey HSD), at $P \leq 0.05$

Species diversity analysis of variance (ANOVA) is significant at probability level $=95 \%$, where; $\mathrm{F}=2.454, \mathrm{df}=(21,234), P=0.000$

Figure 6. Weed species of SEKEM farm, Belbis, Ash Sharqia.

\begin{tabular}{|c|c|c|c|c|}
\hline \multicolumn{2}{|c|}{ Weeds } & \multirow{2}{*}{ Family } & \multicolumn{2}{|c|}{ Geographic Coordinate System (GCS) } \\
\hline Common Name & Scientific name & & Latitude & Longitude \\
\hline Nettle-leaved goosefoot & Chenopodium murale L. & Amaranthaceae & $30^{\circ} 22^{\prime} 58.5^{\prime \prime} \mathrm{N}$ & 31०39'31.1"E \\
\hline Egyptian crowfoot grass & Dactyloctenium aegyptium (L.) Wild. & Poaceae & $30^{\circ} 22^{\prime} 57.8^{\prime \prime} \mathrm{N}$ & 3139'38.7"E \\
\hline Cockspur grass & Echinochloa crus-galli (L.) Beauv. & Poaceae & $30^{\circ} 22^{\prime} 54.8^{\prime \prime} \mathrm{N}$ & 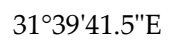 \\
\hline Cogon grass & Imperata cylindrica (L.) Beauv. & Poaceae & $30^{\circ} 22^{\prime} 57.6^{\prime \prime} \mathrm{N}$ & 3139'33.6"E \\
\hline Cheese-weed & Malva parviflora $\mathrm{L}$. & Malvaceae & $30^{\circ} 22^{\prime} 48.0^{\prime \prime} \mathrm{N}$ & 3139'48.5"E \\
\hline Green foxtail & Setaria viridis (L.) Beauv. & Poaceae & $30^{\circ} 23^{\prime} 00.9^{\prime \prime} \mathrm{N}$ & 31०39'29.9"E \\
\hline Broadleaf plantain & Plantago major $\mathrm{L}$. & Plantaginaceae & $30^{\circ} 22^{\prime} 58.5^{\prime \prime} \mathrm{N}$ & 3139'31.1"E \\
\hline Giant pigweed & Trianthema portulacastrum $\mathrm{L}$. & Aizoaceae & $30^{\circ} 22^{\prime} 48.0^{\prime \prime} \mathrm{N}$ & $31^{\circ} 39^{\prime} 48.5^{\prime \prime} \mathrm{E}$ \\
\hline Common Cocklebur & Xanthium strumarium L. & Asteraceae & $30^{\circ} 22^{\prime} 48.0^{\prime \prime} \mathrm{N}$ & 3139'48.5"E \\
\hline
\end{tabular}

Table 7. Diversity indices of medicinal and weed plants at SEKEM.

\begin{tabular}{|c|c|c|c|c|c|c|}
\hline Plant & Taxa (S) & Individuals & D & 1/D & $\mathbf{H}^{\prime}$ & Evenness \\
\hline $\mathrm{Rm}$ & 11 & 78 & 0.148 & 6.748 & 0.881 & 1.041 \\
\hline Mo & 8 & 62 & 0.222 & 4.513 & 0.712 & 0.903 \\
\hline $\mathrm{Ch}$ & 11 & 77 & 0.149 & 6.711 & 0.909 & 1.041 \\
\hline Sa & 9 & 63 & 0.146 & 6.829 & 0.852 & 0.954 \\
\hline La & 7 & 22 & 0.160 & 6.243 & 0.758 & 0.845 \\
\hline B & 11 & 141 & 0.147 & 6.826 & 0.897 & 1.041 \\
\hline Le & 9 & 28 & 0.156 & 6.407 & 0.828 & 0.954 \\
\hline NG & 12 & 206 & 0.217 & 4.612 & 0.785 & 1.079 \\
\hline EGC & 10 & 71 & 0.388 & 2.575 & 0.616 & 1.000 \\
\hline CG & 7 & 43 & 0.213 & 4.703 & 0.722 & 0.845 \\
\hline $\mathrm{CO}$ & 7 & 16 & 0.250 & 4.000 & 0.677 & 0.845 \\
\hline Che & 16 & 307 & 0.217 & 4.614 & 0.788 & 1.204 \\
\hline Grf & 7 & 23 & 0.233 & 4.288 & 0.679 & 0.845 \\
\hline BIP & 12 & 146 & 0.214 & 4.677 & 0.809 & 1.079 \\
\hline GP & 7 & 17 & 0.162 & 6.182 & 0.748 & 0.845 \\
\hline $\mathrm{CC}$ & 8 & 18 & 0.301 & 3.326 & 0.666 & 0.903 \\
\hline
\end{tabular}

Rm: Rosemary, Mo: Moringa, Ch: Chamomile, Sa: Salvia, La: Lavender, B: Basil, Le: Lemongrass, NG: Nettle-leaved goosefoot, EGC: Egyptian

Crowfoot grass, CG: Cockspur grass, CO: Cogon grass, Che: Cheesweed, Grf: Green foxtail, BIP: Broadleaf Plantain, GP: Giant Pigweed and CC: 
Table 8. SEKEM biodiversity and taxa distribution.

\begin{tabular}{|c|c|c|c|c|c|c|c|c|c|c|c|c|c|c|c|c|c|}
\hline Taxa & & & & & & & & & imples & & & & & & & & \\
\hline Genera/Species & $\mathbf{R m}$ & Mo & $\mathrm{Ch}$ & Sa & La & B & Le & NG & EGC & CG & $\mathrm{CO}$ & Che & Grf & BIP & GP & $\mathrm{CC}$ & $\chi^{2}$ \\
\hline Zygoribatula syidi & ++ & & + & + & + & & & + & + & + & + & + & + & + & + & + & $75.642^{*}$ \\
\hline Sheloribates sp. & + & & + & & & + & & + & + & & + & + & + & + & + & + & $48.444^{*}$ \\
\hline Rhizogliphus robini & ++ & + & & ++ & & & + & ++ & + & + & + & + & + & + & + & + & $42.500^{*}$ \\
\hline Typhlodromus athiasea & + & ++ & & & & + & + & + & + & + & + & + & & + & + & + & $74.612^{*}$ \\
\hline Typhlodromus sp. 1 & & & + & + & + & & & & & & & + & & & & & $39.909^{*}$ \\
\hline Parasitus sp. & + & & + & + & & ++ & & & & & & + & & & & & $141.059^{*}$ \\
\hline Macrocholes sp. & + & ++ & + & & + & + & + & + & + & & + & & + & & & & $190.667^{*}$ \\
\hline Laelaspis astronomicus & + & + & + & & + & & + & & + & & & + & & + & & + & $15.308^{\text {ns }}$ \\
\hline Kleemania sp. & & & & & + & & + & & & & + & & + & & & + & $11.000^{\text {ns }}$ \\
\hline Amblyseius sp. 1 & & & & + & & & + & + & & & + & + & + & + & + & & $39.963^{*}$ \\
\hline Amblyseius sp. 2 & + & & + & & & + & & + & & + & & & & + & & & $48.652^{*}$ \\
\hline Ololealaps sp. & & + & & & + & & & & + & + & + & + & & & + & + & $38.571^{*}$ \\
\hline Spinibdella sp. & & & + & & & & + & + & & & & + & & + & & & $86.571^{*}$ \\
\hline T. urticae & & + & & + & & ++ & & +++ & & & & +++ & & & & & $804.433^{*}$ \\
\hline
\end{tabular}

Table 8. cont.

\begin{tabular}{|c|c|c|c|c|c|c|c|c|c|c|c|c|c|c|c|c|c|}
\hline Taxa & & & & & & & & & nples & & & & & & & & $\gamma^{2}$ \\
\hline Taxa & $\mathrm{Rm}$ & Mo & Ch & Sa & $\mathbf{L a}$ & B & Le & NG & EGC & CG & $\mathrm{CO}$ & Che & Grf & BIP & GP & CC & $\chi^{2}$ \\
\hline Hemicheyletia wellsina & + & + & & & & + & & + & & & & + & & + & & & $76.704^{*}$ \\
\hline Collembola & + & + & + & + & + & + & + & & + & + & & + & + & & + & + & $20.103^{\text {ns }}$ \\
\hline Thrips tabaci & & & & ++ & & + & + & & + & ++ & & ++ & & ++ & & & $290.429^{*}$ \\
\hline Bemisia tabaci & & & ++ & & & ++ & & + & & & & +++ & & + & & & $609.565^{*}$ \\
\hline Aphis sp. & ++ & & + & + & & ++ & & +++ & ++ & & & +++ & & +++ & & & $588.235^{*}$ \\
\hline
\end{tabular}

(+) Few specimens 1-10, (++) moderate specimens 11-40, (+++) common specimens $>40$ individuals/sample * Significant, ns not significant at probability level $=95 \%$

Rm: Rosemary, Mo: Moringa, Ch: Chamomile, Sa: Salvia, La: Lavender, B: Basil, Le: Lemongrass, NG: Nettle-leaved goosefoot, EGC: Egyptian Crowfoot grass, CG: Cockspur grass, CO: Cogon grass, Che: Cheese-weed, Grf: Green foxtail, BIP: Broadleaf Plantain, GP: Giant Pigweed and CC: Common Cocklebur.

Table 9. Diversity indices of the arthropod species in SEKEM farm.

\begin{tabular}{cccccccc}
\hline Genera/Species & $\begin{array}{c}\text { Mean/10 leaves } \mathbf{1} \\
\text { SE }\end{array}$ & Taxa (S) & Individuals & (D) & (1/D) & (H') & Evenness \\
\hline Zygoribatula syidi & $5.06 \pm 1.26 \mathrm{c}$ & 12 & 81 & 0.121 & 8.271 & 2.297 & 0.828 \\
Typhlodromus athiasea & $4.20 \pm 1.14 \mathrm{c}$ & 12 & 67 & 0.132 & 7.570 & 2.203 & 0.755 \\
Typhlodromus sp 1 & $0.69 \pm 0.34 \mathrm{~d}$ & 4 & 11 & 0.289 & 3.457 & 1.295 & 0.912 \\
Parasitus sp & $2.13 \pm 1.12 \mathrm{~cd}$ & 5 & 34 & 0.322 & 3.108 & 1.261 & 0.706 \\
Macrocholes sp & $2.25 \pm 1.34 \mathrm{~cd}$ & 10 & 36 & 0.394 & 2.541 & 1.487 & 0.443 \\
Laelaspis astronomicus & $0.81 \pm 0.23 \mathrm{~d}$ & 9 & 13 & 0.136 & 7.348 & 2.098 & 0.906 \\
Tetranychus urticae & $12.13 \pm 6.38 \mathrm{~b}$ & 5 & 194 & 0.322 & 3.108 & 1.292 & 0.728 \\
Kleemania sp & $0.31 \pm 0.12 \mathrm{~d}$ & 5 & 5 & 0.200 & 5.000 & 1.609 & 1.000 \\
Sheloribates sp & $2.25 \pm 0.67 \mathrm{~cd}$ & 11 & 36 & 0.147 & 6.821 & 2.136 & 0.769 \\
Amblyseius sp 1 & $1.70 \pm 0.53 \mathrm{~cd}$ & 8 & 27 & 0.155 & 6.452 & 1.967 & 0.893 \\
Amblyseius sp 2 & $1.44 \pm 0.45 \mathrm{~cd}$ & 6 & 23 & 0.195 & 5.136 & 1.714 & 0.925 \\
Ololealaps sp & $0.88 \pm 0.38 \mathrm{~d}$ & 8 & 14 & 0.235 & 4.261 & 1.772 & 0.735 \\
Spinibdella sp & $0.88 \pm 0.56 \mathrm{~d}$ & 5 & 14 & 0.449 & 2.227 & 1.128 & 0.618 \\
Rhizogliphus robini & $8.00 \pm 1.19 \mathrm{c}$ & 13 & 128 & 0.083 & 12.012 & 2.524 & 0.960 \\
Hemicheyletia wellsina & $1.69 \pm 0.74 \mathrm{~cd}$ & 6 & 27 & 0.240 & 4.165 & 1.592 & 0.819 \\
Collembola & $1.81 \pm 0.40 \mathrm{~cd}$ & 13 & 29 & 0.106 & 9.452 & 2.384 & 0.835 \\
Thrips tabaci & $6.56 \pm 2.82 \mathrm{c}$ & 7 & 105 & 0.235 & 4.248 & 1.659 & 0.751 \\
Bemisia tabaci & $11.50 \pm 5.41 \mathrm{~b}$ & 5 & 184 & 0.270 & 3.709 & 1.437 & 0.842 \\
Aphis sp & $18.13 \pm 6.67 \mathrm{a}$ & 8 & 290 & 0.189 & 5.283 & 1.828 & 0.777 \\
\hline F-value & $\mathbf{2 . 3 1 1}$ & & & & &
\end{tabular}

The means followed by similar letters are not significantly different (Tukey HSD), $\mathrm{df}=(15,151), P=0.001$ at $95 \%$ 
Table 10. Biodiversity similarity indices between the study locations.

\begin{tabular}{ccc}
\hline Experimental location & Total species & Shared species \\
\hline Shampoliah farm & 39 & 14 \\
SEKEM & 35 & \\
\hline Jaccard Index J' & 0.233 & \\
Sørenson Coefficient CC & 0.378 & \\
\hline
\end{tabular}

\section{Figures}

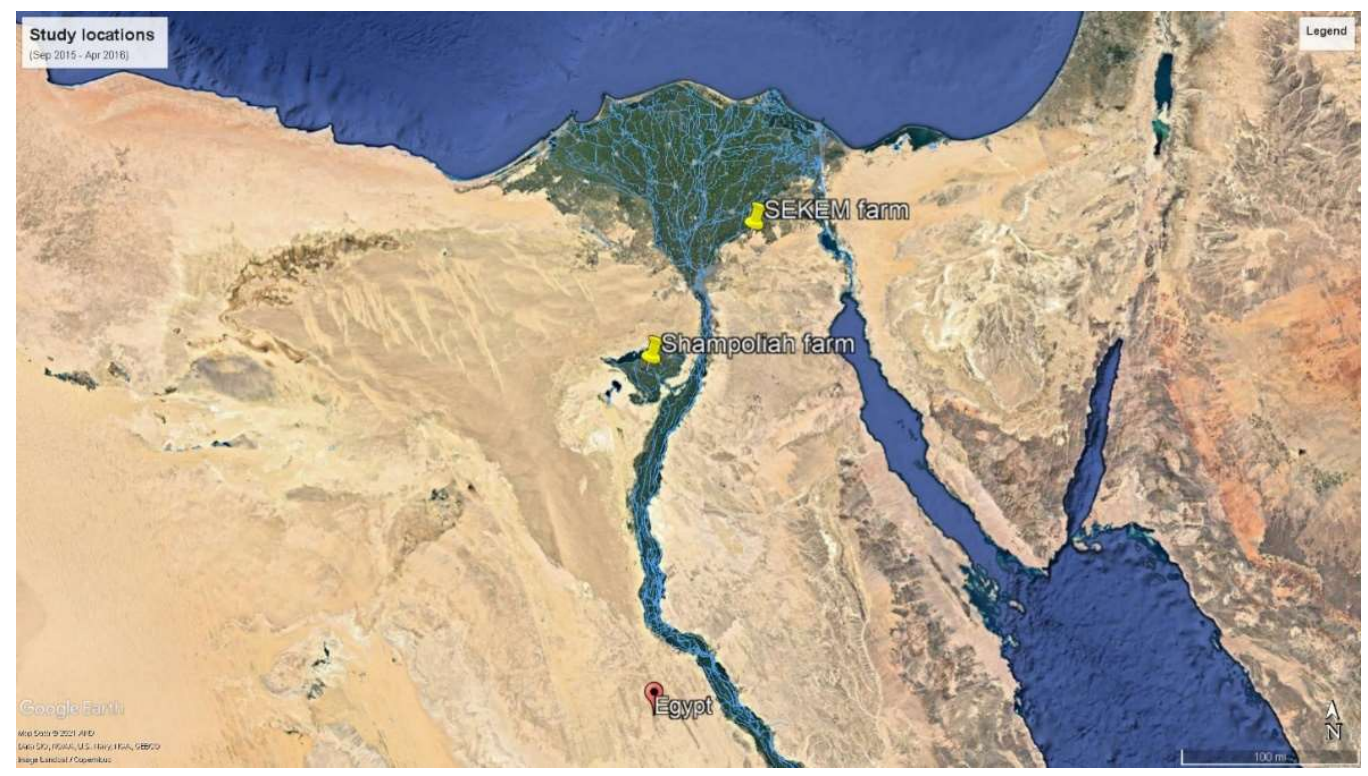

(a)

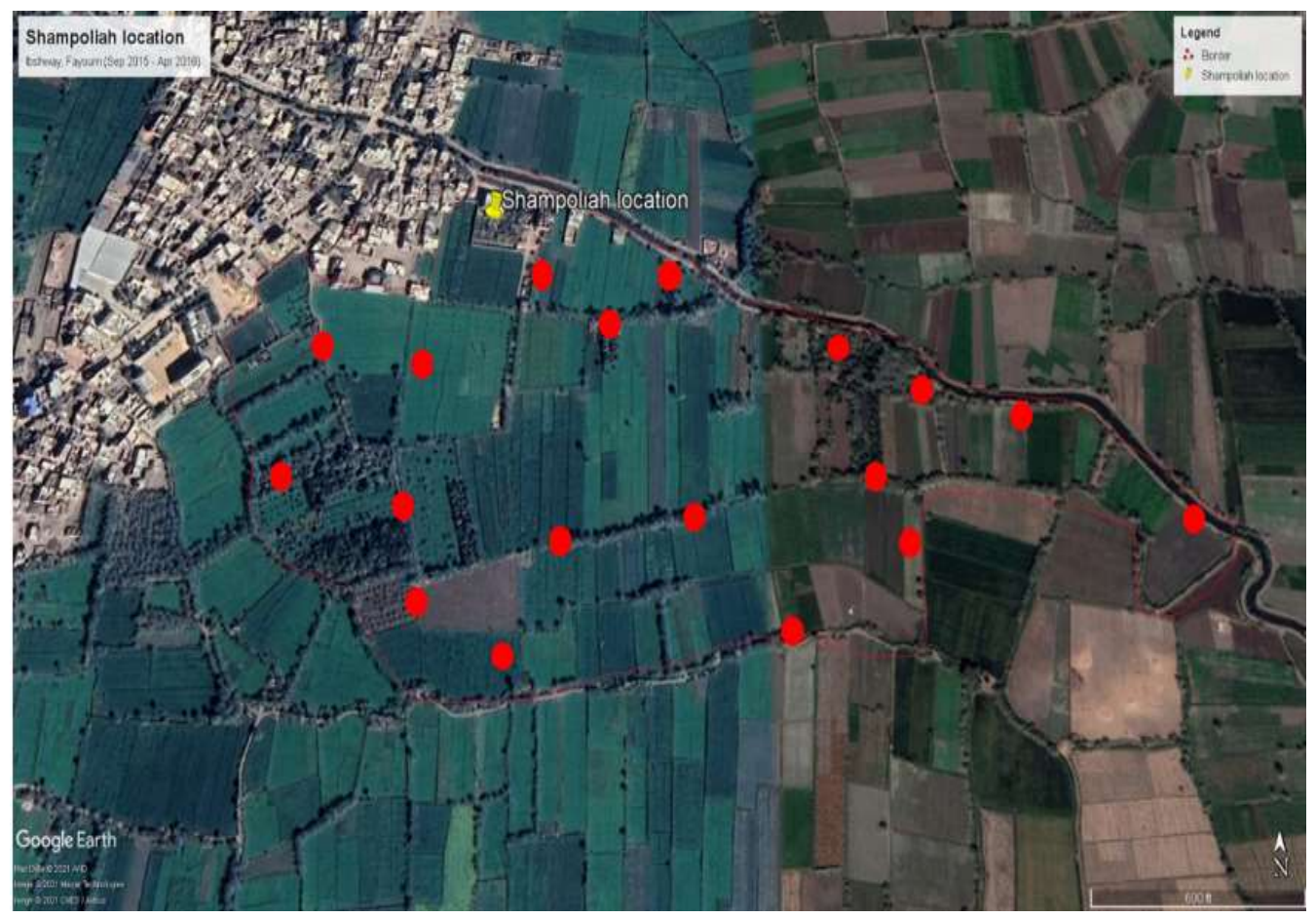

(b) 


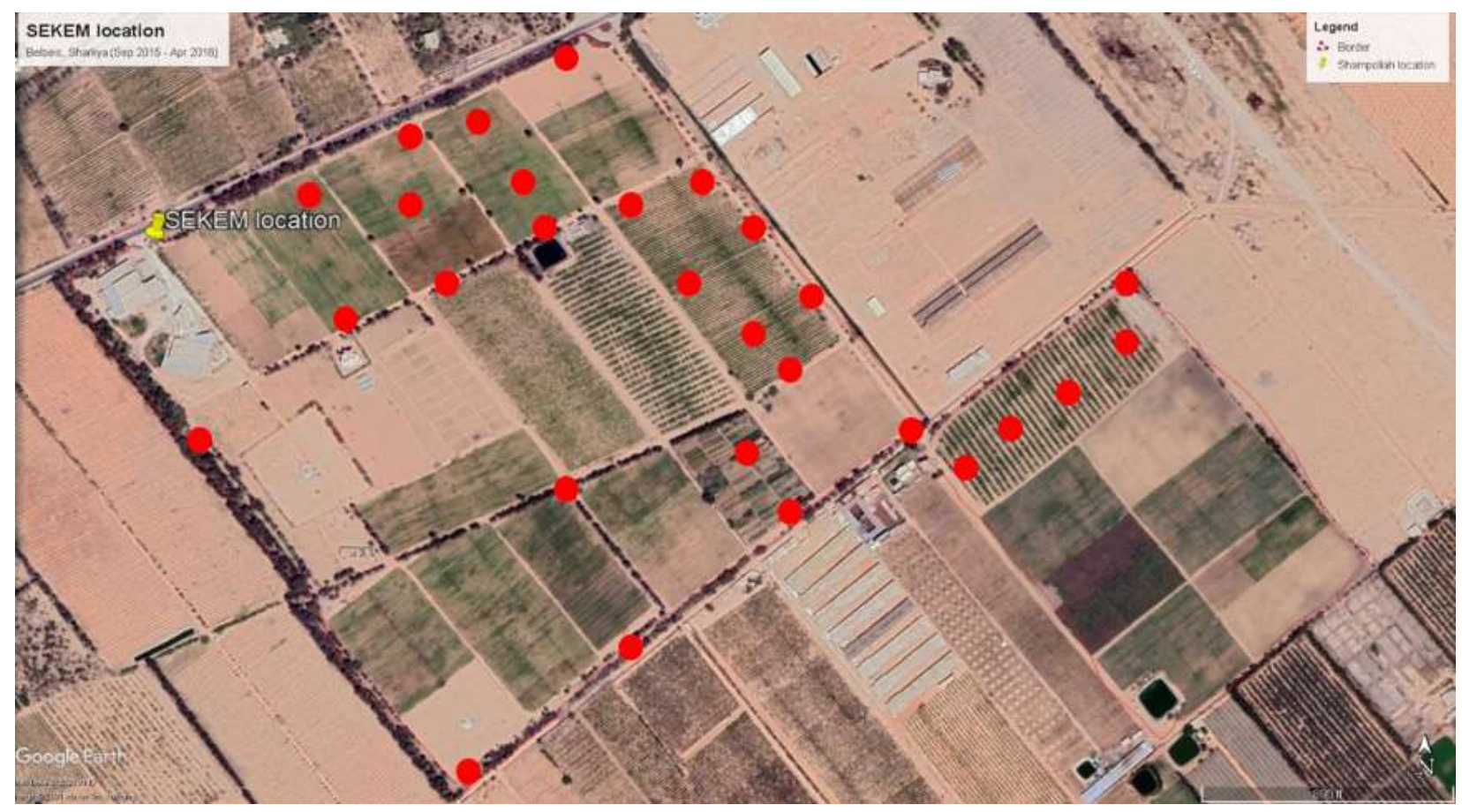

(c)

Figure 1. Experimental locations, a) within the Egypt's map, b) Shampoliah farm, Fayoum (GCS 29²1'07.4"N 304 '17.8"E), and c) SEKEM farm, Sharkia (GCS 30²2'56.1"N 31³9'17.4"E). .

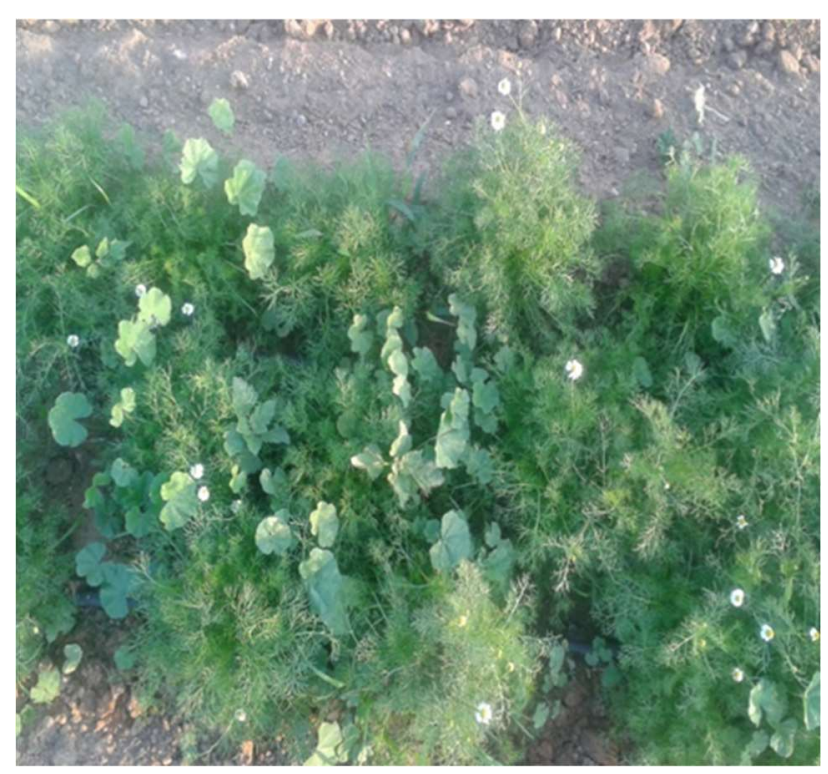

(a)

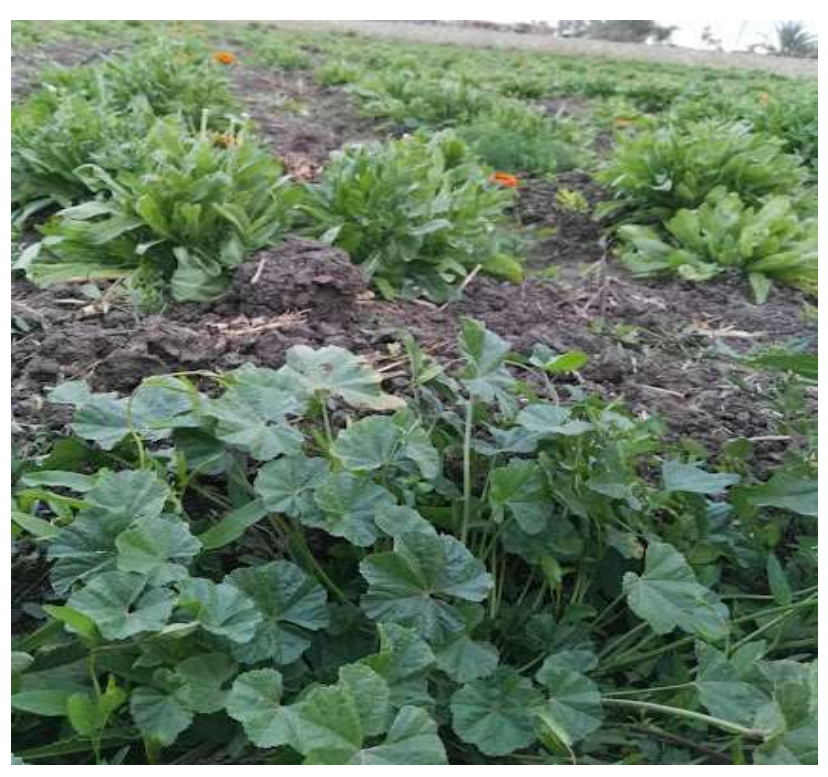

(b)

Figure 2. Cheese weed Malva parviflora, a) with Calendula in Shampoliah, and b) with Chamomile in SEKEM. 


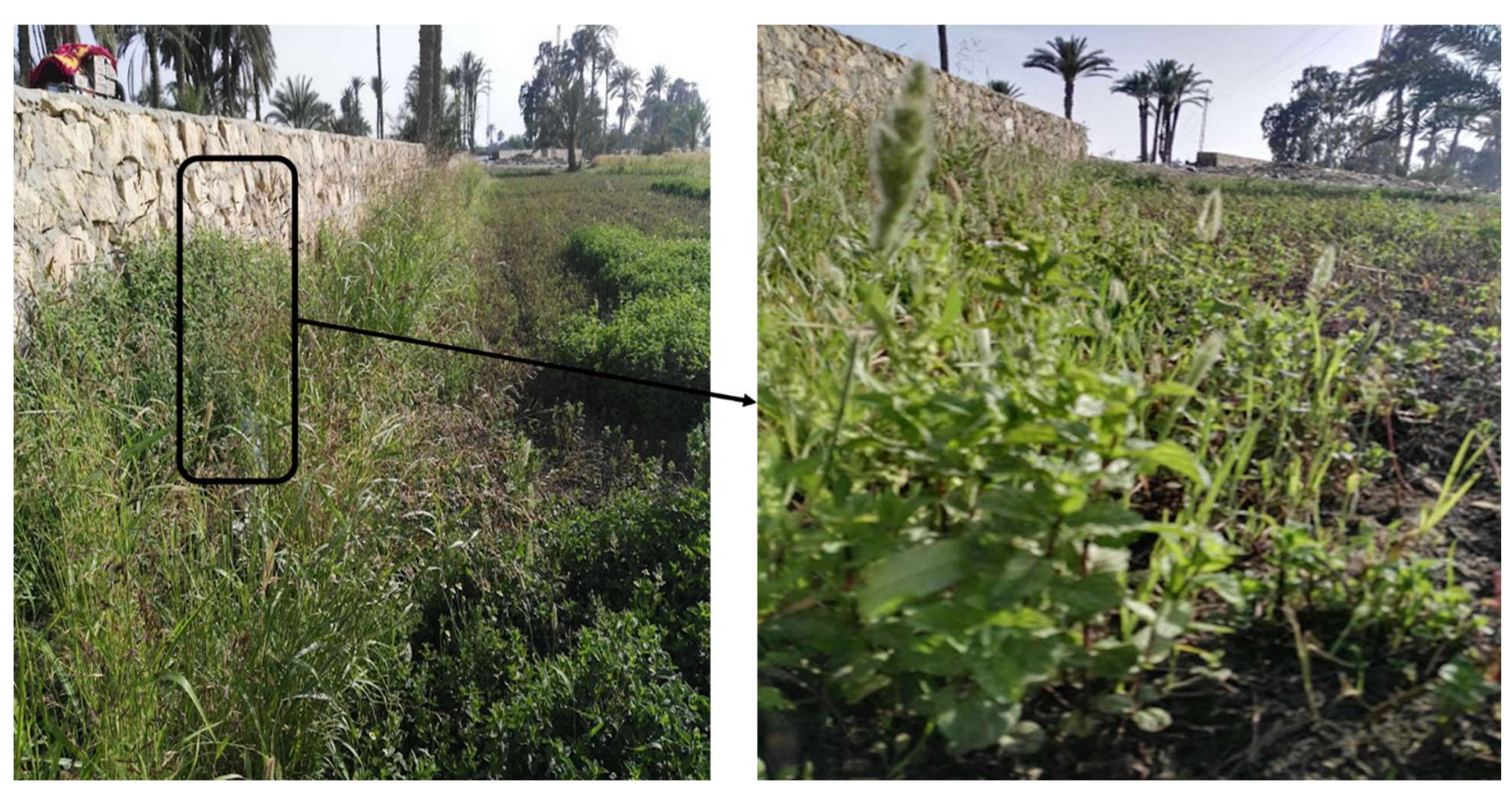

Figure 3. Weeds on boarders hypothesized a positive impact on arthropod distribution. 